\title{
EDUCATION FOR SUSTAINABLE DEVELOPMENT
}

\author{
Luana Mayara de Souza Brandãoa, Priscilla Sayonara de Sousa Brandãoa, Luma \\ Mirely de Souza Brandãob \\ a Universidade do Estado da Bahia, Brazil \\ b Universidade Estácio de Sá, Brazil
}

\begin{abstract}
The environment, for a long time, has been suffering from man-made actions, which is the main responsible for its degradation. Thus, education is a fundamental part of changing this awareness of sustainability. In this sense, this work aims to analyze the importance of education for sustainable development. The methodological approach used was qualitative and bibliographic research, in which the information was collected in books, legislation, articles and government websites. It was found that education is the key to achieve sustainable development, since it guides and teaches individuals to be transformers, aiming to form a sustainable, conscious and responsible community regarding the environment.
\end{abstract}

Keywords: Education; Sustainable Development; Sustainability

\section{EDUCAÇÃO PARA O DESENVOLVIMENTO SUSTENTÁVEL}

Resumo: O meio ambiente, há muito tempo, está sofrendo com as ações provocadas pelo homem, sendo este o maior responsável pela sua degradação. Assim, a educação é parte fundamental para mudar essa consciência quanto à sustentabilidade. Nesse sentindo, esse trabalho tem como objetivo analisar a importância da educação para o desenvolvimento sustentável. A abordagem metodológica utilizada foi a pesquisa qualitativa e bibliográfica, em que as informações foram coletadas em livros, na legislação, em artigos e em sites do governo. Constatouse que a educação é a chave para se alcançar o desenvolvimento sustentável, pois ela orienta e ensina os indivíduos a serem transformadores, visando a formar uma coletividade sustentável, consciente e responsável quanto ao meio ambiente.

Palavras-chave: Educação; Desenvolvimento Sustentável; Sustentabilidade. 


\section{INTRODUCTION}

In recent years, climate change has attracted the attention and concern of numerous scientists and scholars, in view of the negative exponential growth of the impacts of these changes and global warming for society and the environment. Human is largely responsible for this degradation of the environment, since human uses it negligently, inadequately, imprudently and unconsciously, aiming and caring, in most cases, only with profits, with the economic. Thus, it is necessary an Environmental Education that explains, teaches and guides individuals so that individuals are aware of sustainability and the environment and, consequently, can have a good quality of life, without exploring and degrading the environment, instituting the balance between the environment and human [1].

Federal Constitution of 1988 establishes that the ecologically balanced environment is a right of all people, being fundamental to the good quality of life and it is the duty of society and Public Power to protect and preserve it for present and future generations. This constitution emphasizes the importance of Environmental Education is present and strengthened at all levels of education, since it is essential for the good quality of life of the community [2]. Thus, it is necessary to educate to achieve a culture of sustainability.

United Nations (UN) has ratified the importance of education for sustainable development by including quality education as one of the Sustainable Development Goals (SDGs), to ensure quality, inclusive and equal education [3]. Education for sustainable development is essential for individuals to acquire environmental awareness, since it enables that people at all levels of education to have cognition, skills and competences to disseminate fundamental values for conduct aimed at sustainable development [4]. Thus, this work aims to discuss the importance of education for sustainable development.

\section{METHODOLOGY}

To reach the information and knowledge of the present work, the methodological approach based on Godoy [5] was used, which understands that qualitative research has achieved recognition in the learning of phenomena that encompass human beings and their countless and complicated social relations, instituted in many environments. Furthermore, according to this author, qualitative research can be directed through different paths. In addition, this study uses bibliographic research, with the purpose of searching and analyzing information about education for sustainable development. Thus, the information was collected in articles, books, Brazilian legislation and government websites on the subject in question.

\section{EDUCATION FOR A SUSTAINABILITY CULTURE}


Education plays a fundamental role in the construction of the personality and the integral formation of the subject's intellectuality, preparing for social and professional life [6]. Education is the primary regulator of the historical, economic, social, environmental and cultural development of humanity. In addition, education also transmits knowledge and fundamental values for a sustainable living. A way of sustainable living connects with values and morals in the management of the environment and economy, seeking to satisfy the needs of present and future generations [6]. In that sense, according to Gadotti [6]:

\begin{abstract}
Among the pedagogical principles, knowledge and values of a culture of peace and sustainability and of an education focused on the future, we can highlight: educating to think globally; educate with feelings; teach earthly identity; form for planetary consciousness; form for understanding; educate for voluntary simplicity and for stillness [6].
\end{abstract}

Educating to think globally is about educating to change at a regional and global level, educating not to be irresolute, disinterested, silent, negligent and complacent with the extinction of life everywhere on earth. According to Gadotti [6] educating feelings is related to "[...] Educating to feel and make sense, to take care and take care of oneself, to live with meaning in every moment of our lives. We are human because we feel and not just because we think. We are part of a whole under construction". On the other hand, teaching earthly identity is related to educating to achieve an affective bond with the Earth, not to take advantage of it, but to love it. As for training for planetary consciousness, it is associated with understanding that everyone are interdependent, that "the Earth is one nation and we, the earthlings, its citizens. We would not need passports. Nowhere on Earth should we consider ourselves foreigners". Forming for understanding encompasses the idea of educating for dialogue, no communication wanting to explore the other, but to better understand each other and the idea of solidarity. Finally, educating for voluntary simplicity and quietness is related to the notion that life should be guided by values such as simplicity, stillness, peace, understanding, responsibility, listening and finding, performing together [6]. Thus, these principles, values and knowledge are fundamental to a culture of sustainability, in which individuals have a conscious education about the environment and sustainability.

Education is so important for sustainable development that quality education has been included as one of the 17 Sustainable Development Goals, defined by the UN, aiming at sustainable development, determining goals that guarantee a quality, inclusive and equitable education, in verbis: "Ensuring inclusive and equitable and quality education and promoting lifelong learning opportunities for all" [3]. Corroborating this understanding, the United Nations Educational, Scientific and Cultural Organization [4] understands that "Education is the main agent of transformation for Sustainable Development, increasing people's ability to transform their views on society a reality". Thus, quality education is essential to achieve the SDGs, so it is very important that education is transformed, aiming inclusive, equal and accessible education for all.

To achieve sustainable development, equality, insertion and the elimination of poverty, it is necessary to invest in education, since it is the key to sustainable progress, since the constant investment in education makes it possible to achieve quality education. "There is a positive feedback loop between education and 
innovation as a driver of sustainable growth in a green economy, in which innovation, green skills and the ability to deal with change will be significant drivers for each economic sector. Thus, it is necessary to educate for sustainable future, to form a more conscious, sustainable and responsible society in relation to the environment [7].

Education for sustainable development (ESD) is essential for quality education. ESD provides individuals of all levels of education the knowledge, skills and aptitude to propagate essential values for attitudes, behaviors and actions that lead to sustainable development. People have to have conducts, parameters and sustainable consumption models, in short, to have a green education. For this reason, education for sustainable development needs to be promoted and strengthened at all levels of education and educational circumstances. Thus, there is a need for public educational policies, educational programs and conduct, as well as a change in educational systems aimed at sustainability [4]. In this sense, UNESCO [4] aims and understands that:

\begin{abstract}
UNESCO aims to improve access to quality education for sustainable development at all levels and in all social contexts, to transform society through the reorientation of education and to help people develop the knowledge, skills, values and behaviors needed to sustainable development. It is about including issues of sustainable development, such as climate change and biodiversity, in teaching and learning. Individuals are encouraged to be responsible actors who solve challenges, respect cultural diversity and contribute to the creation of a more sustainable world [4].
\end{abstract}

Therefore, when natural resources are limited, everyone must have education for sustainable development, sustainable habits and conduct, in short, have responsibility and awareness of the environment. Thus, Education for Sustainable Development prepares and empowers individuals to transform the way "how they think and work for a sustainable future [7].

\title{
4 ENVIRONMENTAL EDUCATION IN BRAZIL AND SUSTAINABLE DEVELOPMENT
}

Initially, it is interesting to highlight that the environment is so important for the community that the Federal Constitution of 1988 committed a chapter of its text to deal with the protection of the environment. This constitution, in its article 225, paragraph 1

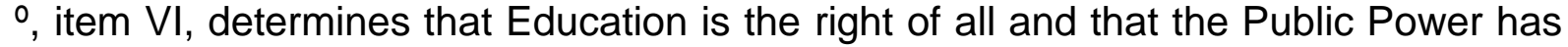
the task of developing it, in verbis: "promoting environmental education at all levels of education and public awareness for the preservation of the environment " [2]. Thus, the Magna Carta emphasizes the importance of environmental education is visible, strengthened and progressed at all levels of education, since it is an essential part of society's quality of life [8].

Even with the implementation of the Federal Constitution, Environmental Education needed its own law capable of promoting effectiveness in determining the Greater Law. In light of this, in 1999, this lack is supplied through the Law n‥ 9,795, which institutes the National Environmental Education Policy, becoming another fundamental advance in the institutionalization of environmental education in Brazil. 
Thus, Environmental Education is an essential component of basic education in Brazil, therefore, it must be present in all levels of education [8].

The aforementioned Law in its first article has already legally defined Environmental Education saying that:

\begin{abstract}
Environmental education is understood as the processes by which the individual and the community build social values, knowledge, skills, attitudes and competences aimed at the conservation of the environment, a common use of the people, essential to a healthy quality of life and its sustainability [9].
\end{abstract}

It appears that the idea of sustainability, of a constitutional character, was introduced in the designation of Environmental Education, since present and future generations are entitled to the sustainable use of natural resources. Therefore, everyone must have this purpose, since Environmental Education is essential to obtain sustainable development [10]. Corroborating this understanding, the Federal Constitution, in its article 225, establishes that: "Everyone has the right to an ecologically balanced environment, a good for the common use of the people and essential to a healthy quality of life, imposing itself on the Public Power and the community the duty to defend and preserve it for present and future generations "[2].

Environmental Education seeks to introduce students to a reflective and critical awareness of environmental problems, since it can be an agent that aims at environmental conservation. And the school is the place where students should expand their knowledge about the environment in a teaching and learning process that contemplates reality in a contextualized way. Environmental education in educational institutions is essential to mitigate the issues and consequences caused by the conduct of human in the environment [11]. Thus, Carvalho [11] explains that:

Children represent here future generations in training. Considering that children are in the stage of cognitive development, it is assumed that in them environmental awareness can be internalized and translated into behaviors more successfully than in adults who, already formed, have a repertoire of crystallized habits and behaviors and difficult reorientation [11].

Therefore, it is necessary and fundamental an Environmental Education in schools, since it aims to guide students and society as a whole to have environmental awareness, to have sustainable thoughts and conduct for the preservation of the environment, with the purpose of sustainable development [8].

\title{
5. CONCLUSION
}

Education is the basis for achieving sustainable development. It is through it that people and societies can acquire skills, abilities, thoughts, knowledge and sustainable awareness. It will guide and teach how these people can adopt more responsible behavior in relation to the environment, how to have a more conscious consumption, not wanting to explore it, but to preserve it. It is clear, then, the importance of Environmental Education is present at all levels of education, as a tool to establish a sustainable culture, in which people start to protect the environment, so that present and future generations have a good quality of life. It is observed that Brazilian legislation demonstrates this importance, determining that environmental education should be developed at all levels of education, in addition to establishing that the 
ecologically balanced environment is the right of all people and that it is the duty of the State and of the community to preserve and defend it.

Therefore, in view of the limitation of natural resources, education is essential for sustainable development to be achieved, since it prepares individuals to have a critical awareness of the environment, having more responsibilities, becoming agents that think about sustainability as a way of having a good quality of life.

\section{REFERENCES}

${ }^{1}$ MEDEIROS, A. B.; MENDONÇA, M. J. S. L.; SOUSA, G. L.; OLIVEIRA, I. P. A Importância da educação ambiental na escola nas séries iniciais. Revista Faculdade Montes Belos, v. 4, n. 1, setembro. 2011.

${ }^{2}$ BRASIL. Constituição da República Federativa do Brasil de 1988. Disponível em:< http://www.planalto.gov.br/ccivil_03/constituicao/constituicao.htm>. Acesso em: 15 jun. 2020.

3BRASIL. NAÇÕES UNIDAS. Educação de qualidade. Disponível em: <https://nacoesunidas.org/pos2015/ods4/>. Acesso em: 25 Jul. 2020.

4BRASIL. Organização das Nações Unidas para a Educação, a Ciência e a Cultura.. Educação para o Desenvolvimento Sustentável. Disponível em: $<$ https://en.unesco.org/themes/education-sustainable-development>. Acesso em: 25 Jul. 2020.

${ }^{5}$ GODOY, A. S. Introdução à Pesquisa qualitativa e suas possibilidades. RAERevista de Administração de Empresas, São Paulo, v. 35, n. 2, 1995.

${ }^{6}$ GADOTTI, Moacir. Educar para a sustentabilidade: uma contribuição à década da educação para o desenvolvimento sustentável. São Paulo: e Livraria Instituto Paulo Freire, 2008. Disponível em: <http://www.acervo.paulofreire.org:8080/jspui/bitstream/7891/3080/1/FPF_PTPF_12 _077.pdf>. Acesso em: 20 Jul. 2020.

${ }^{7}$ BRASIL. Organização das Nações Unidas para a Educação, a Ciência e a Cultura.. Educar para um futuro sustentável. Disponível em: $<$ http://www.unesco.org/new/pt/rio-20/educating-for-a-sustainable-future/>. Acesso em: 25 Jul. 2020.

8VIANA, R. G.; SAMPAIO, D. R; ARAGÃO, R. F. Reflexões sobre a política nacional de educação ambiental como ferramenta de preservação do meio ambiente. Disponível em: < https://jus.com.br/artigos/52317/reflexoes-sobre-a-politica-nacionalde-educacao-ambiental-como-ferramenta-de-preservacao-do-meio-ambiente>. Acesso em: 25 Jul. 2020. 
${ }^{9}$ BRASIL. Lei no 9.795, de 27 de abril de 1999. Disponível em:< http://www.planalto.gov.br/ccivil_03/leis/l9795.htm>. Acesso em: 20 Jul. 2020.

${ }^{10}$ SILVA, R. G. A Lei 9.795/99 e a efetividade da sustentabilidade ambiental. Disponível em: < https://jus.com.br/artigos/51926/a-lei-9-795-99-e-a-efetividade-dasustentabilidade-ambiental >. Acesso em: 22 Jul. 2020.

${ }^{11}$ CARVALHO, I.C.M. Qual educação ambiental?: Elementos para um debate sobre .educação ambiental e extensão rural. Agroecologia e Desenvolvimento Rural Sustentável, Porto Alegre, v. 2, n. 2, p.43-51, abr./jul. 2001. Quadrimestral. Disponível

em:<http://www.emater.tche.br/docs/agroeco/revista/ano2_n2/revista_agroecologia_ ano2_num2_parte11_artigo.pdf $>$. Acesso em: 22 Jul. 2020. 